\title{
PEMBELAJARAN OBJEKTIVIKASI MUSIKAL MELALUI PENGUASAAN MUSIK INSTRUMENTAL BAGI ANAK SEKOLAH DASAR
}

\section{Yohanes Hernawan Pratama}

Prodi Pendidikan Seni, Program Pascasarjana, Universitas Negeri Yogyakarta.

Email: yohanes_pratama@rocketmail.com

\begin{abstract}
Based on the curriculum 2013, the teaching and learning music at SD Marsudirini Semarang Indonesia consists of the instrumental and vocal music learning. The results of the study show that the instrumental music learning activity in the school can improve students' solfeggio that it can support whether the vocal or instrumental music learning activity itself.
\end{abstract}

Key Words: education, music, instrumental, objektifikasi

Abstrak: Berdasar kurikulum 2013, pembelajaran musik di SD Marsudirini Semarang Indonesia, terdiri dari pembelajaran musik instrumental dan vokal. Dalam hasil penelitian terhadap pembelajaran, ditemukan bahwa pembelajaran musik instrumental di sekolah dapat meningkatkan kemampuan solfegio siswa sehingga dapat mendukung pembelajaran vokal maupun musik instrumental itu sendiri.

Kata kunci: pendidikan, musik, instrumental, objektifikasi 


\section{PENDAHULUAN}

Dari sejarahnya, tradisi musik yang datang ke Nusantara dari akhir abad ke-15 hingga ke-18 adalah tradisi solmisasi, suatu teori musik yang diciptakan oleh seorang rahib Guido de Arrezo, yang dibawa oleh kaum misionaris Spanyol dan Portugis. Solmisasi itu kemudian menyebar ke banyak daerah di Nusantara di masa kolonial Belanda, khususnya ketika muncul sebuah sekolah guru untuk Gereja Protestan Indonesia (GPI) dalam naungan Nederlansch Zendelinggenootschap (Persekutuan para penginjil Belanda) di Ambon sekitar tahun 1818 dimana sekolah tersebut telah menjadi pusat bagi pengajaran agama Kristen Protestan di seluruh Nusantara, terkecuali Batak Toba, yang dilaksanakan oleh Rheinische Missions Gesellschaft.

Tradisi solmisasi dalam pendidikan musik di Nusantara masih berlangsung hingga saat ini, hal ini ditunjukkan dengan masih jarang sekolah-sekolah umum yang memanfaatkan instrumen alat musik sebagai pokok pembelajaran dalam pendidikan musiknya, hampir semua instansi pendidikan formal memberikan materi vokal kepada siswa namun instrumen alat musik hanya digunakan sebagai pengiring dalam pembelajaran vokal. Hal ini disebabkan oleh beberapa faktor; instrumen vokal di sekolah memiliki kelebihan, yaitu: 1) tidak memerlukan biaya dalam pengadaan alat; 2) siswa langsung paham maksud dan isi dari sebuah karya lagu yang dinyanyikan; namun demikian instrumen vokal juga memiliki kelemahan, yaitu: 1) memiliki ketergantungan pada instrumen alat musik dalam hal penyeteman; 2) siswa hanya secara instan menerima karya lagu bersyair yang sudah jelas isi dan maksudnya, sehingga abstraksi sebuah karya tidak luas; 3) timbre suara vokal hanya terbatas pada suara anakanak, wanita, dan pria; serta 4) ambitus suara vokal hanya terbatas pada tangga nada tertentu. Sedangkan instrumen alat musik membutuhkan biaya dalam pengadaan alat untuk pembelajaran, namun memiliki kelebihan, yaitu: 1) intonasi lebih stabil; 2) dapat membantu siswa untuk peka pada nada yang tepat; 3) timbre instrumen lebih beragam; 4) ambitus suara instrumen lebih luas bila dibandingkan suara vokal; dan 5) dengan mempelajari instrumen alat musik, siswa dapat terbantu dalam mempelajari instrumen vokal, sehingga kemampuan menembak nada yang tepat dalam vokal dapat meningkat.
Tulisan ini ingin menggali efektifitas pembelajaran objektivikasi musik instrumental dalam pendidikan seni pada kompetensi hasil belajar siswa. Kompetensi hasil belajar sendiri adalah perubahan perilaku ataupun perbuatan pebelajar setelah mengalami belajar (Soehardjo 2012: 60), dalam hal ini kemampuan solfegio siswa, dengan mengambil contoh kasus pelaksanaan pembelajaran musik di Sekolah Dasar Marsudirini kota Semarang, Indonesia.

Solfegio

Solfegio adalah latihan kemampuan pendengaran atau ketajaman pendengaran musik, baik ketepatan ritmik maupun ketepatan nadanya.Menurut Stanly yang dikutip Sumaryanto (2005:40) dikatakan Solfegio adalah istilah yang mengacu pada menyanyikan tangga nada, interval dan latihan-latihan melodi dengan sillaby solmization yaitu, dengan menyanyikan solmisasi (do,re,mi,dst) dan kemudian dikembangkan dengan menempatkan huruf vokal (a,i,u,e,o) sebagai ganti solmisasi. Solfegio juga dapat diartikan sebagai ilmu dalam memahami interval musik dan notasi. Solfegio bertujuan untuk memberikan pemahaman tentang jarak nada satu ke nada yang lain dengan cara menyanyikan berbagai macam bentuk notasi, dengan menyanyikan interval nada yang berbeda-beda. Biasanya solfegio diajarkan dengan latihan-latihan menyanyikan solmisasi yang terus bertambah tingkat kesulitannya. Dalam perkembangannya solfegio bukan hanya menyanyi saja tetapi juga mendengar dan membaca nada. Kemampuan membaca nada disebut dengan Sight Reading, kemampuan mendengar nada disebut dengan Ear Training, sedangkan kemampuan menyanyi disebut dengan Sight Singing.

\section{Konsep Pendidikan Seni}

Pendidikan seni adalah pendidikan yang menggunakan seni sebagai bahan kajiaannya (Soehardjo 2011: 13). Berdasarkan rujukan resmi Undang-undang Republik Indonesia nomor 2 tahun 1989 tentang Sistem Pendidikan Nasional: Pendidikan adalah usaha sadar untuk menyiapkan peserta didik melalui kegiatan bimbingan, pengajaran, dan/atau latihan bagi peranannya di masa yang akan datang. Sedangkan pengertian seni berdasarkan analisis adalah kegiatan berkesenian yang selanjutnya diuraikan bahwa kegiatan berkesenian itu terdiri dari 2 jenis: 
Yohanes Hernawan Pratama

PEMBELAJARAN OBJEKTIVIKASI MUSIKAL MELALUI PENGUASAAN MUSIK INSTRUMENTAL

BAGI ANAK SEKOLAH DASAR

kegiatan berkesenian yang dilandasi modus imitasi, dan yang dilandasi mosud ekspresi. Bila memadukan pengertian pendidikan dan seni itu sendiri, maka pengertian hakiki Pendidikan Seni adalah usaha sadar untuk menyiapkan peserta didik melalui kegiatan bimbingan melalui kegiatan bimbingan, pengajaran, dan atau latihan agar menguasai kemampuan berkesenian sesuai dengan peran yang harus dimainkannya. Ada dua peran yang dapat dimainkan. Pertama, menularkan keterampilan seni, dan yang kedua memfungsididikkan seni (Read, 1945 dan Wickiser, 1974 dalam Soehardjo 2011: 13).

Seni dan Estetika mempunyai konstelasi pengetahuan yang berbeda dengan pengetahuan eksak. Struktur pengetahuan seni dan estetika ini selanjutnya disebut sebagai Logika Seni atau Logika Estetika (logico aestheticus); logika yang berbasis rasa dan cara pemerolehannya (epistemologinya) dengan pengakuan terlebih dahulu. Dalam konstelasi pengetahuan seni mendekati filsafat yang dasar pemahamannya melalui perenuangan dan pengalaman (eksperiensial). Sedangkan pendidikan masuk dalam polus behavioral sciences oleh karenanya pendidikan berada pada ilmu dan sosial. Polus behavioral sciences menuntut pemikran dengan eksperimensial atau percobaan agar tidak terjadi kesalahan dalam penerapannya. Logika, baik saintikus maupun estetikus bersifat dinamis oleh perubahan masyarakat termasuk filsafat (cara berpikir kritis, sosial, budaya dan perkembangan jiwa maupun politik kenegaraan). Pendidikan Seni berada pada dua ranah (polus) yang menghendaki kekhasan, karena berada pada ranah berbeda. Untuk memahami perkembangan masyarakat perlu didahului dengan pengantar tinjauan sosiologis, filsafat, psikologis dan budaya menuju habitus serta prioritas kenegaraan (Pamadhi 2015: 6)

\section{A. METODE PENELITIAN}

Dalam sebuah penelitian yang baik harus menggunakan metode yang benar dan tepat, untuk mendapatkan jawaban yang dibutuhkan peneliti. Sesuai dengan apa yang disampaikan oleh Rohidi (2011: 179) bahwa penelitian seni hendaknya menggunakan metode pengumpulan data secara sistematik yang berkaitan dengan berbagai bentuk karya seni (rupa, tari, musik, pertunjukan, dan sebagainya), dari sebuah individu, kelompok masyarakat, satuan budaya, atau lingkungan tertentu, yang menjadi latar kehadiran karya seni yang berkaitan. Rohidi menerapkan suatu pendekatan penelitian yang dianggap lebih faktual dan praktis. Sebagai pedoman dalam menentukan metode penelitian tentang seni, maka digunakan pendekatan interdisiplin. Dalam penelitian objektivikasi musikal melalui penguasaan musik instrumental ini menggunakan metode deskriptif kualitatif.

\section{Lokasi dan Waktu Penelitian}

Penelitian ini dilakukan di SD Marsudirini Semarang, Indonesia yang terletak di jalan Pemuda 157-159 Semarang. Penelitian ini dilakukan selama satu setengah bulan yaitu mulai pertengahan bulan Februari sampai dengan akhir bulan Maret 2015.

\section{Sasaran Penelitian}

Adapun sasaran penelitian ini adalah proses pembelajaran ansambel musik di kelas III A sampai dengan III C di SD Marsudirini Semarang. Sasaran penelitian proses pembelajaran hanya diambil sampel tiga kelas dengan alasan pada tiga kelas tersebut terdapat jumlah siswa dengan pembagian yang merata. Siswa-siswi SD Marsudirini yang memiliki nilai rata-rata tinggi pada kelas sebelumnya, di kelas III akan dikelompokkan dalam kelas III paralel A dan $\mathrm{C}$, sehingga apabila penulis mengambil sampel dari kelas III A sampai dengan III C maka akan didapat sampel responden yang merata dari kelompok siswa dengan rata-rata tinggi hingga menengah.

\section{Teknik Pengumpulan Data}

Penelitian dalam rangka mengungkap proses pembelajaran objektivikasi musikal melalui penguasaan musik instrumental yang dilaksanakan melalui kegiatan ansambel musik di SD Marsudirini Semarang. Teknik yang digunakan dalam penelitian ini adalah: observasi, wawancara (interview), dan dokumentasi.

\section{Teknik Pemeriksaan Keabsahan Data}

Untuk menetapkan keabsahan data dalam penelitian kualitatif diperlukan pemeriksaan. Pelaksanaan teknik pemeriksaan didasarkan atas sejumlah kriteria tertentu. Kriteria/Standar keabsahan data kualitatif yang penulis pergunakan dalam penelitian ini adalah derajad kepercayaan (credibility). Kriteria ini 
menuntut penelitian kualitatif agar dapat dipercaya oleh pembaca yang kritis dan dapat dibuktikan oleh orang-orang yang menyediakan informasi yang dikumpulkan selama penelitian berlangsung (Wagiman 2011: 51).

Dalam penelitian ini akan dipergunakan teknik pemeriksaan keabsahan data triangulasi untuk memastikan derajad keabsahan data. Triangulasi adalah verifikasi penemuan melalui informasi dari berbagai sumber dan menggunakan multi metode dalam pengumpulan data. Untuk menguji keabsahan data dipergunakan triangulasi data. Pengujian dilakukan dengan cara: (1) membandingkan data hasil wawancara dengan kepala sekolah dan guru seni musik, (2) membandingkan data hasil observasi dengan data hasil wawancara dengan guru seni musik, dan (3) membandingkan hasil wawancara dengan dokumen yang ditemukan (Moleong dalam Wagiman 2011: 51).

\section{Teknik Analisis Data}

Analisis data adalah upaya yang dilakukan dengan jalan bekerja dengan data, mengorganisasikan data, memilah-milahnya menjadi satuan yang dapat dikelola, mensintesiskannya, mencari dan menemukan pola, menemukan apa yang penting dan apa yang dipelajari, dan memutuskan apa yang dapat diceritakan kepada orang lain (Bogdan dan Biklen dalam Moleong 2010: 248).

Proses pengolahan data dimulai dengan mengelompokkan data-data yang terkumpul melalui observasi, wawancara, dokumentasi, dan catatan yang dianggap dapat menunjang dalam penelitian ini untuk diklarifikasikan dan dianalisis berdasarkan kepentingan penelitian. Hasil analisis data tersebut selanjutnya disusun dalam bentuk laporan dengan teknik deskriptif analisis yaitu dengan cara mendeskripsikan keteranganketerangan atau data-data yang telah terkumpul dan dianalisis berdasarkan teoriteori yang ada.

Menurut Miles dan Huberman (dalam Maudina 2015: 48), analisis data terdiri atas tiga tahap, yaitu reduksi data, penyajian data, dan penarikan kesimpulan/verifikasi.

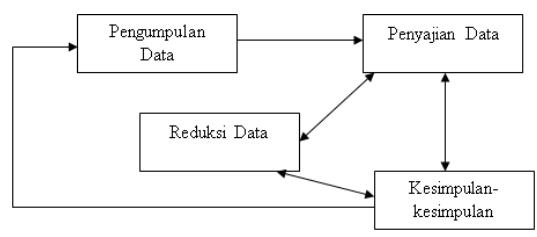

Gambar 1 Analisis Model Interaktif

Sumber: Analisis Data Kualitatif (Miles \& Huberman dalam Maudina 2015: 48)

\section{Reduksi data (Data Reduction)}

Menurut Sugiyono, mereduksi data artinya merangkum, memilih hal-hal yang pokok, memfokuskan pada hal yang penting, dicari tema dan polanya (Maudina 2015: 49). Dalam penelitian ini pola dan tema penelitian adalah meneliti pembelajaran objektivikasi musikal melalui penguasaan musik instrumental dalam pembelajaran ansambel musik di SD Marsudirini Semarang, dengan tujuan untuk mengumpulkan data dan memilih data yang telah diperoleh untuk dihasilkan hasil penelitian.

\section{Penyajian data}

Penyajian data penelitian kualitatif. Bentuk penyajian data dengan teks yang bersifat naratif merupakan cara yang paling umum digunakan. Hal tersebut akan memudahkan dalam menyajikan data-data yang diperoleh mengenai pembelajaran objektivikasi musikal melalui penguasaan musik instrumental yang dilaksanakan dalam pembelajaran ansambel musik di SD Marsudirini Semarang.

\section{Verifikasi/simpulan}

Simpulan yang dikemukakan bersifat sementara dan akan berubah jika ditemukan bukti lain yang kuat. Peneliti akan memperoleh kesimpulan sebagai hasil akhir pengolahan data.

\section{Pembelajaran Objektivikasi Musikal Melalui Penguasaan Musik Instumental}

Pengajaran musik adalah pengajaran tentang bunyi. Apapun yang dibahas dalam suatu pembelajaran musik harus bertitik tolak dari bunyi itu sendiri. Unsur-unsur yang paling dasar dan sangat penting dalam suatu lagu, ialah irama dan melodi. Dalam kegiatan bernyanyi maupun bermain musik kita harus dapat merasakan gerak irama lagu dan ayunan biramanya, serta dapat membayangkan nada dan melodi lagu tersebut dalam pikiran atau khayalan. Oleh sebab itu untuk mengajarkan unsur irama haruslah dapat ditanamkan, dipupuk, ditingkatkan, dan dikembangkan pengertian serta rasa irama. Untuk mengajarkan unsur melodi juga harus dapat menanamkan, memupuk, meningkatkan, dan mengembangkan pengertian serta 


\section{BAGI ANAK SEKOLAH DASAR}

mempertajam bayangan nada. Kedua hal itu dapat dicapai melalui pengalaman musik. Tanpa mempunyai rasa irama dan bayangan nada, orang hanya akan bernyanyi atau bermain musik seperti robot, tidak merasakan dan menghayati ungkapan lagu yang dinyanyikan atau dimainkannya. Tegasnya, kemampuan merasakan irama dan kemampuan membayangkan nada adalah syarat urutan kemampuan yang harus ditanamkan terlebih dahulu dalam belajar musik (Jamalus 1998: 3).

Tantangan dalam pendidikan seni musik di sekolah dasar sekarang adalah mendasari kemampuan musikal yang merupakan syarat urutan kemampuan ini, Dalam penelitian ini diungkapkan bahwa penguasaaan musik instrumental pada anak mampu memberikan objektivikasi musikal. Objektivikasi sendiri artinya adalah kegiatan merepresentasikan suatu objek melalui suatu proses dalam diri yang dilaksanakan secara sadar. Untuk lebih memberikan pemahaman tentang objektivikasi, akan penulis berikan contoh objektivikasi dari karya Plato dalam periode perkembangan pemahaman seni dari tinjauan filsafat. Tulisan Plato sangat banyak dan berbentuk dialog; dalam dialog ini pembaca harus menginterpratasi masing-masing kata atau kalimat yang tersusun (excergessis). Keindahan hadir karena kesenian dan kesenian menjadi hadir dari suatu pengamatan, baik langsung maupun tidak langsung. Proses penciptaan tersebut memerlukan keterampilan teknis untuk menyadap keindahan bentuk alami dan kemudian hadir melalui imajinasi. Bentuk yang hadir merupakan duplikasi (imitasi) dari benda alami (ars imitatur naturam). Peniruan tadi disyaratkan bahwa sebuah karya seni hadir karena fisik dan idealisme. Fisik yang dimaksud adalah kemampuan instrumen mata untuk menangkap objek; melalui keterampilan bentuk itu dihadirkan kembali sebagai imitasi. Langkah ke dua adalah kehadiran ide yang ada dalam bentuk; ide dapat dipahami dan dikenali sehingga tersimpan dalam memori. Ide ini akhirnya menjadi ideologi sebuah penciptaan karya seni patung sebagai representasi imajinasi bentuk alami.

Dari uraian di atas penciptaan karya seni oleh Plato dicapai dengan dua langkah, (1) techne dan (2) poesis; techne adalah kemampuan menyatakan bentuk yang mewakili visi objektivikasi sehingga orang menyatakan kemiripan (ars imitatur naturam). Seni merupakan peniruan bentuk alam yang mampu memberikan gambaran (imajinasi) bagi yang melihat. Poesis adalah proses pengubahan (mimesis) bentuk alami menjadi lebih indah tanpa menghadirkan bentuk aslinya. Karya menjadi semacam tata bentuk yang menimbulkan kesamaan imajinasi terhadap objek yang dicontoh dan proses mencontoh karya melalui interpretasi keindahan objek alami.

'Techne sebenarnya adalah sistem pengetahuan dan keterampilan manusia yang membawa segala sesuatu dari gelap menjadi terang' (Bagus Wiryomartono, 2001:5). Seni merupakan transformasi bentuk yang didasari oleh interpretasi indah pada suatu objek. Techne tidak sekedar mereproduksi bentuk melainkan interpretasi terhadap bentuk yang memungkinkan menjadi 'indah'. Penemuan 'indah' melalui pengetahuan dari dialog; pencarian nilai indah dihasilkan dari dialog tersebut sehingga menemukan bentuk 'imajiner' yang sempurna.

a. Plato Mengungkapkan bahwa sastra atau seni hanya merupakan peniruan (mimesis) atau pencerminan dari kenyataan.

b. Aritoteles Ia berpendapat bahwa mimesis bukan hanya sekedar tiruan, bukan sekedar potret dan realitas, melainkan telah melalui kesadaran personal batin pengarangnya.

c. Raverzt berpendapat bahwa mimesis dapat diartikan sebagai sebuah pendekatan yang mengkaji karya seni dan sastra yang berupaya untuk mengaitkan karya seni dengan realita atau kenyataan.

d. Abrams Mengungkapkan pendekatan mimetic adalah pendekatan kajian seni dan sastra yang menitikberatkan kajiannya terhadap hubungan karya dengan kenyataan di luar karya.

Periode mimesis dibangun oleh Plato dan dikembangkan oleh muridnya Aristoteles; mimesis menjadi sebuah metode penciptaan karya seni namun juga dapat berfungsi sebagai alat untuk memahami karya seni. Seni merupakan imitasi alami, artinya melalui instrumen mata dan eksperimentasi dihasilkan karya seni. Seni hadir melalui imajinasi objek 
nyata, melalui tangkapan imajinasi diungkapkan kembali dalam bentuk karya seni imitasi. (Pamadhi 2015: 11-12) Gagasan ini dapat digunakan untuk memahami konsep objektivikasi suatu karya seni. Pembelajaran seni berkiblat pada pengalaman rasa yang bersifat individual, serta berintikan kegiatankegiatan motorik (A.J. Soehardjo: Pendidikan Seni 2011: 249).

Untuk memberikan pengalaman rasa pada anak maka diperlukan penerapan objektivikasi musikal melalui musik instrumental yang dapat digambarkan sebagai berikut:

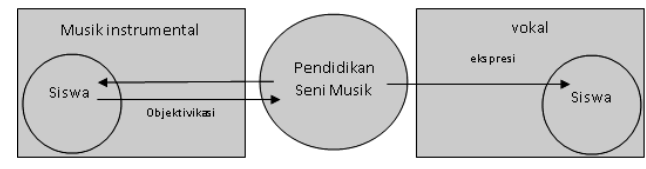

Gambar 2 Objektivikasi Musik Instrumental

Pelaksanaan pembelajaran objektivikasi musikal dilakukan melalui musik instrumental, dimana siswa diajak untuk secara tidak langsung mengasah solfegio yaitu belajar merasakan ritmis, melodi, dan harmoni melalui pelaksanaan pembelajaran musik instrumental. Objektivikasi musikal tidak hanya berhenti pada siswa mempelajari karya seni musik sebagai subyek, namun diharapkan setelah siswa memahami suatu subyek, lalu diinterpretasikan menjadi suatu bentuk lain. Sebagai contoh, setelah siswa melaksanakan pembelajaran objektivikasi musikal melalui musik instrumental yang memiliki intonasi yang jelas dan tepat, maka siswa telah belajar solfegio dalam hal ketajaman pendengaran dan ketepatan nada, setelah pembelajaran diharapkan kemampuan kepekaan siswa meningkat, sehingga materi ini mampu diinterpretasikan siswa misalnya dalam bernyanyi siswa tahu mana nada yang tepat dan mana nada yang false.

\section{Pelaksanaan Pendidikan Seni Musik di SD Marsudirini Semarang Indonesia}

Pembelajaran pendidikan seni musik di SD Marsudirini dimulai sejak kelas III sampai dengan kelas VI menggunakan materi ansambel musik. Seluruh siswa dari kelas III SD dibekali dasar musikalitas melalui musik instrumental yang dimainkan secara bersama dalam bentuk ansambel campuran pianika dan recorder. SD Marsudirini melalui pendidikan seni musik memiliki komitmen utama untuk membentuk siswa menjadi anak yang baik, bukan hanya mahir bermain musik. Hal ini ditunjukkan dari pengambilan nilai siswa bukan hanya diambil dari kemahiran siswa bermain alat musik namun nilai diambil dari sikap rajin siswa membawa alat musik dan partitur; sikap saling menghormati ketika siswa belajar memainkan alat musik secara bersama; siswa juga dituntut untuk setia pada satu alat musik yang ingin didalami sejak kelas III sampai dengan kelas VI Sekolah Dasar, alat yang menjadi pilihan adalah pianika dan recorder; siswa juga dituntut untuk rutin belajar alat musik dan diberi pengertian bahwa berlatih memainkan alat musik perlu ketekunan.

Selain komitmen utama yang dibentuk SD Marsudirini dalam pendidikan seni musik, Guru seni musik di SD Marsudirini memiliki metode pembelajaran yang dinilai efektif mengasah kemampuan solfegio siswa, sejak kelas III SD (usia sekitar 8-9 tahun) pembelajaran ansambel musik sudah menggunakan notasi balok dan nama mutlak, sehingga siswa sejak dini mengenal bahasa universal musik yaitu notasi balok. Melalui ansambel musik siswa mengalami pembelajaran objektivikasi musikal, secara langsung siswa belajar ketepatan nada melalui instrumen pianika dan rekorder, dan secara tidak langsung belajar ketepatan ritmis melalui notasi balok dalam partitur sederhana yang dibuat oleh guru musik.

Dalam pembelajaran pendidikan seni musik di kelas VI di SD Marsudirini, pelaksanaannya dapat dikatakan hampir tidak ada kendala, dikarenakan sejak siswa duduk di kelas III sudah dibekali dasar-dasar musik yang kuat melalui cara-cara sederhana yang bersifat kontinuitas. Hampir semua siswa kelas VI SD Marsudirini memiliki keterampilan bermain alat musik rekorder dan pianika yang baik, juga ketepatan nada saat bernyanyi yang baik pula, hal ini disebabkan oleh latihan solfegio yang dilaksanakan sejak kelas III sampai dengan kelas VI yang bersifat kontinuitas.

\section{PENUTUP}

Pembelajaran objektivikasi musikal melalui penguasaan musik instrumental yang ditanamkan sejak dini terbukti meningkatkan kemampuan solfegio anak, selain juga pendidikan seni mampu melatih karakter siswa. Dengan adanya penelitian di Sekolah Dasar di Indonesia ini diharapkan dapat 
Yohanes Hernawan Pratama

PEMBELAJARAN OBJEKTIVIKASI MUSIKAL MELALUI PENGUASAAN MUSIK INSTRUMENTAL

BAGI ANAK SEKOLAH DASAR

memberikan gambaran serta tawaran pembelajaran pendidikan musik yang efisien di sekolah umum pada negara-negara berkembang.

DAFTAR PUSTAKA

A.J. Soehardjo. 2011. Pendidikan Seni jilid 1. Malang: Bayumedia Publishing.

$$
\text { 2012. Pendidikan Seni jilid } 2 .
$$

Malang: Bayumedia Publishing.

Kennedy, Michael. 1990. The Oxford Dictionary of MUSIC. New York: Oxford University Press.

Maudina, Lifara Aidlika. 2015. Proses Pembelajaran Artikulasi Lagu Dalam Pembelajaran Vokal Untuk Anak Usia 7 Tahun (Studi Kasus di All Mozart Music Course \& Studio Kudus). Skripsi. Semarang: UNNES.

Moleong, J.Lexy. 2010. Metodologi Penelitian Kualitatif. Bandung: PT. Remaja Rosdakarya.

Pamadhi, Hajar. 2015. Materi Perkuliahan: Teori Pendidikan Seni. Yogyakarta.

Rohidi, Tjetjep Rohendi. 2011. Metodologi Penelitian Seni. Semarang: Cipta Prima Nusantara.

Sumaryanto, F. Totok. 2007. Pendekatan Kuantitatif dan Kualitatif Dalam Penelitian Pendidikan Seni. Semarang: Jurusan Sendratasik Fakultas Bahasa dan Seni UNNES.

Wagiman, Joseph. 2011. Implementasi Kurikulum Tingkat Satuan Pendidikan (KTSP): Peranan Guru Dalam Pembelajaran Seni Musik di SMA CITISCHOOL Semarang. Tesis. Semarang: UNNES.

Wullner, Franz. Chorubungen. Jepang 